\title{
PURIFICATION OF $\alpha$-ACETOLACTATE DECARBOXYLASE FROM LACTOBACILLUS CASEI DSM 2547
}

\author{
by
}

\author{
ANNE M. RASMUSSEN, RICHARD M. GIBSON, SVEN ERIK GODTFREDSEN" \\ and \\ MARTIN OTTESEN
}

Department of Chemistry, Carlsberg Laboratory, Gamle Carlsbergvej 10, DK-2500 Copenhagen Valby

" Present address: Novo Industri A/S, Novo Allé, DK-2880 Bagsvaerd

Keywords: $\alpha$-acetolactate, $\alpha$-acetolactate decarboxylase, acetoin, diacetyl, lactic acid bacteria, beer maturation, HPLC

a-Acetolactate decarboxylase has been purified to homogeneity, by fast protein liquid chromatography and high performance elution chromatography, from a partially purified $\alpha$-acetolactate decarboxylase preparation from Lactobacillus casei DSM 2547 . The pure enzyme exhibited a specific activity of $375 \mathrm{kU} \cdot \mathrm{mg}^{-1}$ and exerted its optimal activity at $\mathrm{pH} 4.5$ to 5.0 and at a temperature of $40^{\circ} \mathrm{C}$. Its isoelectric point was estimated to $\mathrm{pH} 4.7$ and its molecular weight was found to be 48,000 . The enzyme was inhibited by o-phenanthroline and could be partially reactivated by zinc ions. An HPLC method for the determination of $\alpha$-acetolactate is described.

\section{INTRODUCTION}

Enzymes with the ability to decarboxylate $\alpha$-acetolactate are widely found amoung bacterial strains but not in other groups of microorganisms $(7,8,10)$. The only $\alpha$-acetolactate decarboxylase (EC 4.1.1.5.) which has been isolated in homogeneous form is the enzyme from Aerobacter aerogenes isolated in 1970 by LøKEN and Størmer (12). This enzyme has more recently been demonstrated to be effective for removal of $\alpha$-acetolactate from freshly fermented beer and thus for acceleration of the beer maturation process (6). However, the practical use of this procedure is complicated by a limited stability of the Aerobacter $\alpha$-acetolactate decarboxylase at the $\mathrm{pH}$ of beer (7). A search for an enzyme with higher stability in the acid $\mathrm{pH}$ region led, among others $(7,8,10)$, to an $\alpha$-acetolactate decarboxylase in a strain of Lactobacillus casei which met this criteria $(8,9)$. This enzyme removed as expected all $\alpha$-acetolactate from freshly fermented beer within $48 \mathrm{hrs}$. However, attemps to use the enzyme during the main fermentation of beer were unsuccessful due to removal of zinc atoms from the enzyme by the rapidly metabolizing yeast cells. Since this was a

Abbreviations: $\mathrm{ALDC}=\boldsymbol{\alpha}$-acetolactate decarboxylase; $\mathrm{AUFS}=$ absorbance units full scale; $\mathrm{BSA}=$ bovine serum albumin; DSM = Deutsche Sammlung von Mikroorganismen; EDTA = ethylene diaminetetraacetic acid; HPEC = high performance exclusion chromatography; HPLC $=$ high performance liquid chromatography. 
clear demonstration that the $\alpha$-acetolactate decarboxylase from Lactobacillus differed from the enzyme from Aerobacter $(6,12)$ attempts were made to purify the enzyme.

The present paper describes the purification and characterization of the $\alpha$-acetolactate decarboxylase from Lactobacillus casei DSM 2547.

\section{MATERIALS AND METHODS}

\subsection{Materials}

O-acetyl-acetolactate ethyl ester (the precursor for the substrate (D,L)- $\alpha$-acetolactate), was synthesized and its purity checked by gas chromatography as described in (6).

Thiamine pyrophosphate and $n$-hexylamine were obtained from Sigma Chemical Co., USA. Gel filtration and ion-exchange resins were from Pharmacia, Uppsala, Sweden. Ampholines were supplied by LKB, Sweden, and creatine monohydrate was obtained from Fluka AG, Switzerland. Other reagents were obtained from Merck, Darmstadt, FDR and were of analytical grade.

\subsection{Methods}

\subsubsection{Determination of $\alpha$-acetolactate decar- boxylase activity}

$\alpha$-Acetolactate solutions were prepared immediately before use by mixing O-acetyl-acetolactate ethyl ester with $0.1 \mathrm{M}$-sodium hydroxide in a ratio of $1: 100$ by volume. When the starting material had dissolved, the solution was incubated for $5 \mathrm{~min}$ at $37^{\circ} \mathrm{C}$ to complete the reaction. $200 \mu \mathrm{l}$ aliquots of the resulting $0.05 \mathrm{M}$-acetolactate solution were mixed with $200 \mu \mathrm{l}$ of acetate buffer $(1.0 \mathrm{M}, \mathrm{pH} 5.0)$ and $600 \mu \mathrm{l}$ of enzyme solution. The enzymatic decarboxylation was allowed to proceed for $30 \mathrm{~min}$ at $37^{\circ} \mathrm{C}$ before the reaction was terminated by addition of $1 \mathrm{ml} 2.5$ M-sodium hydroxide. $100 \mu \mathrm{l}$ aliquots of the reaction mixtures were diluted with $1.1 \mathrm{ml}$ water containing $1.0 \mathrm{mg}$ creatine and the colorimetric acetoin determination was started by addition of $200 \mu$ l of $\alpha$-naphthol solution ( $50 \mathrm{mg}$ per $\mathrm{ml} 2.5$ $\mathrm{M}-\mathrm{NaOH}$ ). After incubation for 1 hour at room temperature the absorbance was measured at $520 \mathrm{~nm}$. Since, in solutions at $\mathrm{pH} \mathrm{5}$, $\alpha$-acetolactate undergoes a slow non-enzymatic oxidative decarboxylation into diacetyl which gives a similar colour reaction with creatine plus $\alpha$-naphthol $(4,21)$ a reagent blank was run without the enzyme. In addition, a calibration curve was made for each assay by mixing $100 \mu \mathrm{l}$ aliquots of the reagent blank with 2,4 , and $6 \mu \mathrm{g}$ of acetoin, adding creatine and $\alpha$-naphthol and measuring the colour after 1 hour as described above. One unit of enzyme activity is defined as the amount of enzyme that forms $1 \mu$ mole of acetoin per hour at $37^{\circ} \mathrm{C}(12)$. Since the colour formation was linearly related to the amount of acetoin only within a range from approx. $2 \mu \mathrm{g}$ to $5 \mu \mathrm{g}$ per $\mathrm{ml}$ assay solution, it was necessary to adjust the enzyme samples to contain between 1.0 and 2.5 units of activity per assay.

As a supplement to the colorimetric determination of acetoin a high performance liquid chromatography (HPLC) method was developed which directly determines the residual amount of $(\mathrm{D}, \mathrm{L})$ - $\alpha$-acetolactate. A Waters liquid chromatography system was used with a C-18 reverse phase radial compression column $(10 \mathrm{~cm}$ $\times 0.5 \mathrm{~cm}, 10 \mu \mathrm{m}$ Nova-Pak). Elution was performed isocratically with $0.01 \mathrm{M}$-di-ammonium hydrogen phosphate containing $2 \%$ acetonitrile and $0.2 \%$ n-hexylamine adjusted to $\mathrm{pH} 7.3$ with ortho-phosphoric acid. The flow rate was 60 $\mathrm{ml} \cdot \mathrm{h}^{-1}$ and peaks were detected by measurement of absorbance at $210 \mathrm{~nm}$. $a$-Acetolactate was eluted as an assymetrical peak with a retention time of approx. $4.5 \mathrm{~min}$. Acetoin and diacetyl were not eluted under these conditions. It was found that use of a new column required conditioning with a small amount of protein. In this study $4 \mathrm{mg}$ of oxidized ribonuclease was used to achieve adequate peak separation (3).

\subsubsection{Isolation procedures}

Partially purified $\boldsymbol{\alpha}$-acetolactate decarboxylase was prepared as described from a 250 litre culture of Lactobacillus casei fermented by Chr. Hansens Laboratory (10). The resulting solution, containing $3350 \mathrm{kU}$ in $1.9 \mathrm{l}$, was concentrated to $600 \mathrm{ml}$ by ultrafiltration and then divided into six aliquots each of which was dialysed against distilled water $\left(51,20 \mathrm{hrs}, 5^{\circ} \mathrm{C}\right)$. After centrifugation at $10.000 \mathrm{~g}$ for $15 \mathrm{~min}$ the supernatant from each portion was adjusted to pH 8.0 with $0.1 \mathrm{M}-\mathrm{NaOH}$ and applied to a 
column $(\mathrm{d}=30 \mathrm{~mm}, \mathrm{~h}=112 \mathrm{~mm})$ of Fractogel DE $650 \mathrm{~S}$ anion exchanger previously equilibrated with $25 \mathrm{mM}$-Tris buffer, $\mathrm{pH} 8.0$ at room temperature. Elution was performed at room temperature with a linear sodium sulphate gra$\operatorname{dient}(350 \mathrm{ml} 25 \mathrm{mM}$-Tris buffer, $\mathrm{pH} 8.0$ and 350

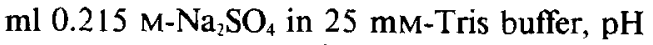
8.0 , flow rate $220 \mathrm{ml} \cdot \mathrm{h}^{-1}$ ) and fractions containing $\alpha$-acetolactate decarboxylase activity were pooled and dialysed at $2{ }^{\circ} \mathrm{C}$ against distilled water ( 10 volumes). Enzyme containing fractions from two columns were pooled and rechromatographed on the same Fractogel column.

The column was regenerated in situ with 110 $\mathrm{ml} 0.2 \mathrm{M}-\mathrm{HCl}$, distilled water until the eluent $\mathrm{pH}$ was $4,110 \mathrm{ml}$ of $0.2 \mathrm{M}-\mathrm{NaOH}$, distilled water until the eluent $\mathrm{pH}$ was 8 and finally equilibrated with the Tris buffer.

Each enzyme pool obtained by rechromatography on Fractogel was dialyzed as before and concentrated by ultrafiltration to $1 \mathrm{ml}$ in an Amicon stirred cell, Model 8010, equipped with an Amicon YM 10 filter. The resulting enzyme solution was applied to a Pharmacia FPLC Mono Q column type HR 5/5 previously equilibrated with $10 \mathrm{mM}$-Tris, $\mathrm{pH} 8.0$ at room tempe- rature. This column was similarly eluted with a linear gradient of sodium sulphate $(30 \mathrm{ml}$ of 10 mM-Tris at pH 8.0 and $30 \mathrm{ml} 0.215 \mathrm{M}-\mathrm{Na}_{2} \mathrm{SO}_{4}$ in $10 \mathrm{~mm}$-Tris buffer, $\mathrm{pH} 8.0$, flow rate $60 \mathrm{ml} \cdot \mathrm{h}^{-1}$ ). Fractions containing $\alpha$-acetolactate decarboxylase activity were pooled, dialysed at $2{ }^{\circ} \mathrm{C}$ against water ( 10 volumes), and again concentrated by ultrafiltration to $1 \mathrm{ml}$. The concentrated enzyme solutions were rechromatographed twice as above on the Mono $Q$ column whereupon enzyme containing fractions were pooled and concentrated to $1 \mathrm{ml}$. This solution was divided into aliquots of $100 \mu 1$ and further purified by high performance gel filtration on a TSK 3000 column (flow rate $33 \mathrm{ml} \cdot \mathrm{h}^{-1}$, eluent: $0.1 \mathrm{M}-\mathrm{Na}_{2} \mathrm{SO}_{4}$ in $50 \mathrm{mM}$-phosphate buffer at $\mathrm{pH} 6.7$ ). The fractions containing $\alpha$-acetolactate decarboxylase were pooled and stored at $-20^{\circ} \mathrm{C}$.

\subsubsection{Molecular weight}

Molecular weight was estimated by means of high performance gel filtration using a TSK 3000 column as described in section 2.2.2 after calibration with ferritin, catalase, bovine serum albumin, ovalbumin, chymotrypsinogen $\mathrm{A}$ and

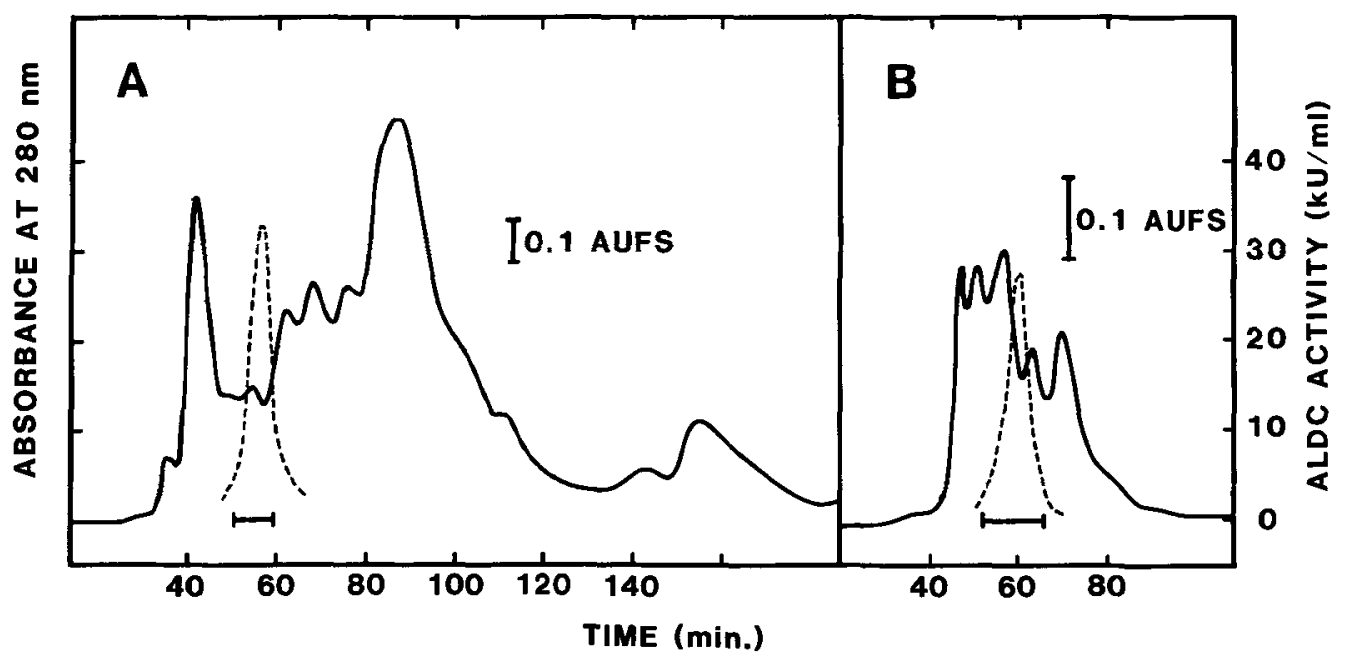

Figure 1. A: Chromatography of $670 \mathrm{mg}$ of $\alpha$-acetolactate decarboxylase, purified as in (10), on a Fractogel DE $650 \mathrm{~S}$ column at room temperature with a linear gradient of $350 \mathrm{ml} 25 \mathrm{~mm}$-Tris, $\mathrm{pH} 8.0$ and $350 \mathrm{ml}$ of $0.215 \mathrm{M}-\mathrm{Na}_{2} \mathrm{SO}_{4}$ in $25 \mathrm{~mm}$-Tris, pH 8.0 , flow $220 \mathrm{ml} \cdot \mathrm{h}^{-1}$. (- ) indicates ALDC activity and $(\longmapsto)$ the fractions pooled. B: Rechromatography of fractions from A, $109 \mathrm{mg}$ protein. The resulting pool (-1) was applied to a Mono Q column as shown in Figure 2. 


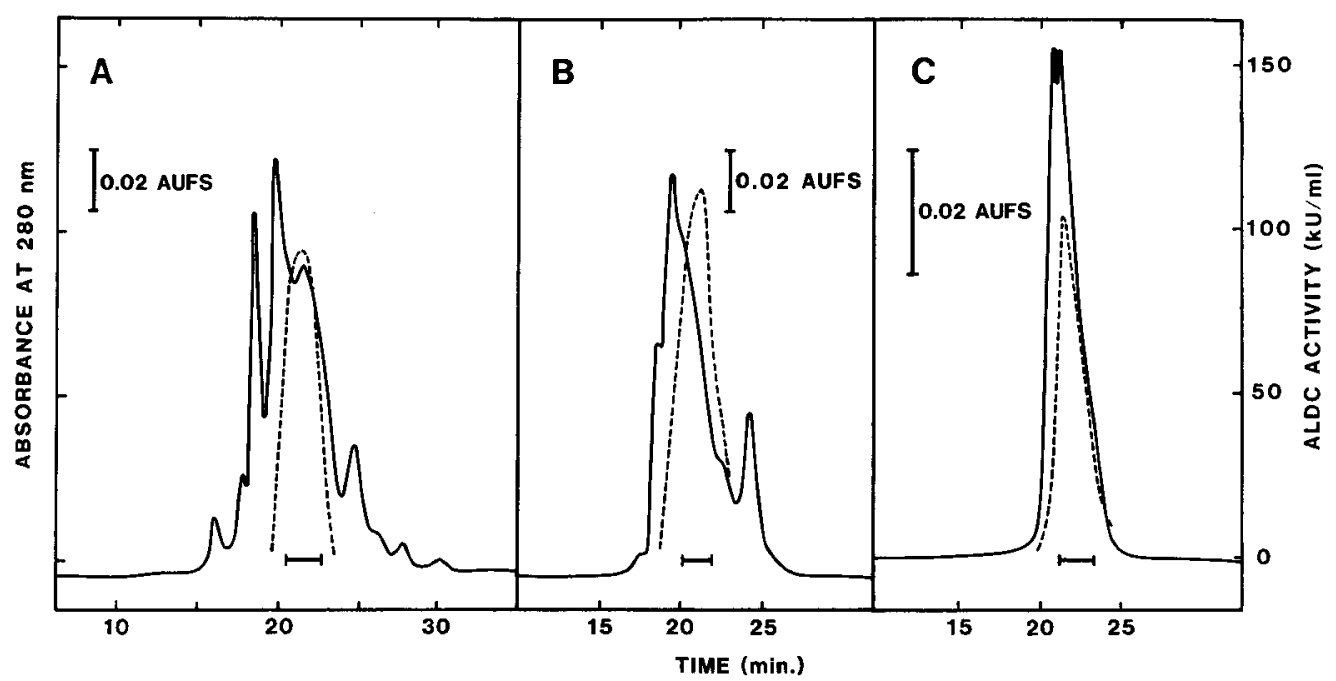

Figure 2. A: Chromatography of $3.5 \mathrm{mg}$ of the resulting pool from the second Fractogel DE chromatography (Figure $1 \mathrm{~B}$ ) on a Mono Q HR 5/5 column at room temperature with a linear gradient of $30 \mathrm{ml}$ of $10 \mathrm{~mm}$-Tris,

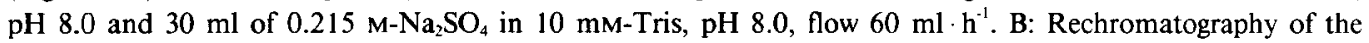
pool from A ( $\longmapsto), 2.4 \mathrm{mg}$. C: Rechromatography of the pool from B, $1.4 \mathrm{mg}$ yielding $0.4 \mathrm{mg}$ of protein. $(--)$ indicates ALDC activity.

cytochrome c.

Molecular weight under denaturing conditions was determined by SDS polyacrylamide gel electrophoresis using homogeneous slabs (1 $\mathrm{mm} \times 140 \mathrm{~mm} \times 80 \mathrm{~mm}, 7.5 \%$ polyacrylamide gel) with the Weber and Osborn SDS-phosphate continuous buffer system in the Pharmacia Apparatus GE-2/4 as described in the Pharmacia Fine Chemicals laboratory Manual (14). $\beta$-Mercaptoethanol was omitted from the sample buffer and the Pharmacia LMW kit was used for molecular weight calibration.

\subsubsection{Isoelectric focusing}

Isoelectric focusing was carried out with $4 \%$ ampholines at $\mathrm{pH}$ 4-6 in a sucrose gradient using the LKB 110 column as described by the manufacturer.

\subsubsection{Amino acid analysis}

Amino acid analysis were performed with a Durrum Model D-500 automatic analyser after hydrolysis of the samples at $110^{\circ} \mathrm{C}$ with $6 \mathrm{M}-\mathrm{HCl}$ in evacuated tubes for $24 \mathrm{hrs}$.

\subsubsection{Optical rotation}

Optical rotation was measured using a Perkin Elmer model 141 Polarimeter fitted with a $1 \mathrm{ml}$ capacity cell of $1 \mathrm{dm}$ pathlength. Rotations were measured at $589 \mathrm{~nm}$ and $20^{\circ} \mathrm{C}$.

\section{RESULTS}

\subsection{Isolation of $\alpha$-acetolactate decarboxylase}

The starting material for the isolation of $\alpha$-acetolactate decarboxylase from Lactobacillus casei DSM 2547 had already undergone chromatography steps on DE and CM cellulose as described in (10). Further purification on the relatively slow DE-cellulose and CM-cellulose columns resulted in great loss of activity while it was found that better results were obtained with resins and columns which could be operated at higher flow rates: approx. $670 \mathrm{mg}$ of the partially purified enzyme could be chromatographed on Fractogel DE $650 \mathrm{~S}$, as described in section 2.2.2, within $3 \mathrm{hrs}$ at room temperature with a five fold purification as seen from Figure $1 \mathrm{~A}$ and Table I. When $\alpha$-acetolactate decarboxylase from two runs on the Fractogel column were combined and rechromatographed on the same 
A.M. RASMUSSEN et al.: $\alpha$-Acetolactate decarboxylase from L.casei

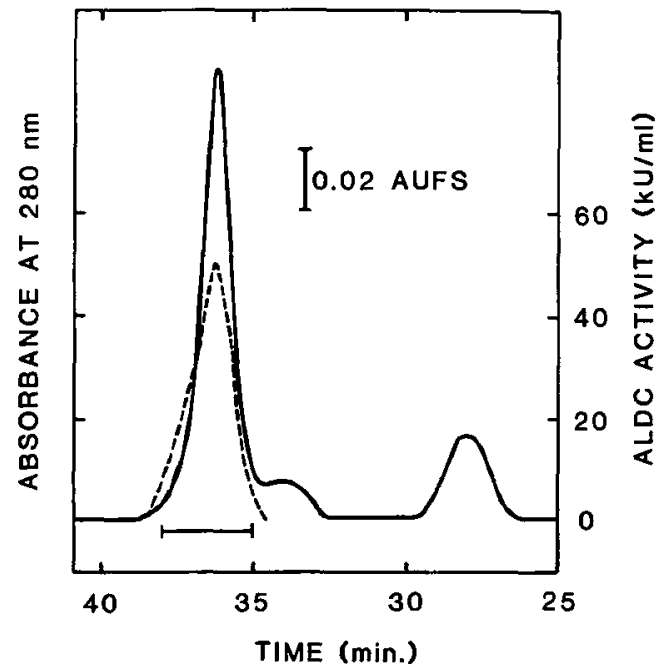

Figure 3. HPEC chromatography of $0.30 \mathrm{mg}$ of the resulting $\alpha$-acetolactate decarboxylase preparation from the Mono $\mathrm{Q}$ column on a TSK 3000 column with a flow rate of $33 \mathrm{ml} \cdot \mathrm{h}^{-1}$, eluent $0.1 \mathrm{M}-\mathrm{Na}_{2} \mathrm{SO}_{4}$ in $50 \mathrm{~mm}$-phosphate, $\mathrm{pH} 6.7$. The fractions with ALDC activity (- $)$ were pooled ( $(-)$ and contained $0.09 \mathrm{mg}$ of pure enzyme.

column an additional seven fold purification was achieved (Figure I B) while further rechromatography on this column did not result in additional purification.

However, when a Mono Q column was used as described in section 2.2.2, the preparation from

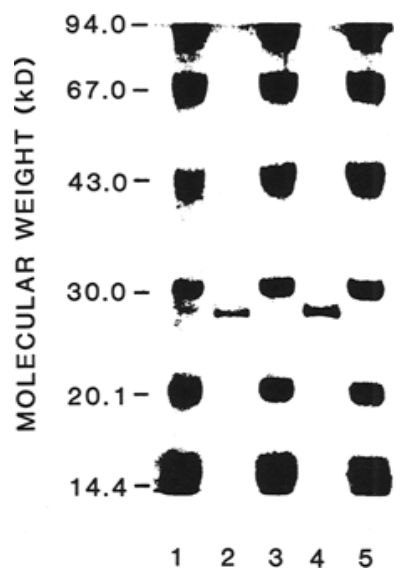

Figure 4. SDS gel electrophoresis of the pure $\alpha$-acetolactate decarboxylase obtained by a final HPEC chromatography. Lanes 2 and 4 contain approximately $3.2 \mu \mathrm{g}$ of the enzyme in non-reduced and reduced form, respectively. Lanes 1, 3 and 5 contain LMW standards.

the Fractogel column separated in many protein components, as shown in Figure $2 \mathrm{~A}$. Repeated rechromatography on the Mono $Q$ column eliminated most impurities (Figure $2 \mathrm{~B}$ and $\mathrm{C}$ ) but a high performance gel filtration step was required to obtain homogeneous $\alpha$-acetolactate decarboxylase (Figure 3), as judged by SDS gel electrophoresis (Figure 4). The purification scheme in Table I shows that the final product

Table I.

Purification scheme of $\alpha$-acetolactate decarboxylase from a 250 I fermentation of Lactobacillus casei DSM 2547.

\begin{tabular}{lclllc}
\hline Fraction and step & $\begin{array}{l}\text { Protein } \\
\mathrm{mg}\end{array}$ & $\begin{array}{l}\text { Total ALDC } \\
\mathrm{kU}\end{array}$ & $\begin{array}{l}\text { Specific activity } \\
\mathrm{kU} \cdot \mathbf{m g}^{\prime \prime}\end{array}$ & $\begin{array}{l}\text { Enzyme Yield } \\
\%\end{array}$ & $\begin{array}{l}\text { Purification } \\
\text {-fold }\end{array}$ \\
\hline $\begin{array}{l}\text { Supernatant of homogenized } \\
\text { L.casei cells }\end{array}$ & $1,500,000$ & 18,700 & 0.012 & 100 & 1 \\
$\begin{array}{l}\text { ALDC purified } \\
\text { as in (10) }\end{array}$ & 18,000 & 3,350 & 0.21 & 18 & 18 \\
After ultrafiltration & 5,480 & 5,070 & 1 & 27 & 83 \\
and dialysis & & & & & \\
Fractogel, run 1 & 670 & 3,270 & 5 & 18 & 416 \\
Fractogel, run 2 & 90 & 2,890 & 33 & 16 & 2,750 \\
Mono Q, run 1 & 8 & 990 & 125 & 5 & 10,300 \\
Mono Q, run 2 & 4 & 990 & 250 & 5 & 20,600 \\
Mono Q, run 3 & 3 & 815 & 270 & 4 & 23,000 \\
HPEC & 1 & 375 & 375 & 2 & 31,000 \\
\hline
\end{tabular}


Table II.

The amino acid composition of a 24 hrs hydrolyzate of $\alpha$-acetolactate decarboxylase from L.casei. Trp and Cys were not determined.

\begin{tabular}{lclr}
\hline $\begin{array}{l}\text { Amino } \\
\text { acid }\end{array}$ & $\begin{array}{c}\text { Mole } \\
\%\end{array}$ & $\begin{array}{l}\text { Amino } \\
\text { acid }\end{array}$ & $\begin{array}{c}\text { Mole } \\
\%\end{array}$ \\
\hline Asp & 9.1 & Ile & 3.5 \\
Thr & 7.6 & Leu & 12.3 \\
Ser & 3.2 & Tyr & 2.2 \\
Glu & 11.3 & Phe & 6.4 \\
Pro & 4.6 & His & 4.6 \\
Gly & 11.0 & Lys & 5.4 \\
Ala & 9.4 & Arg & 2.6 \\
Val & 6.8 & & \\
\hline
\end{tabular}

with a specific activity of $375 \mathrm{kU} \cdot \mathrm{mg}^{-1}$ was obtained by 31,000 fold purification and that only $1 \mathrm{mg}$ of $\alpha$-acetolactate decarboxylase was obtained from the original 250 litres of fermentation liquid.

\subsection{Physico-chemical characterization}

The molecular weight of native $\alpha$-acetolactate decarboxylase was estimated to be 48,000 by means of high performance gel filtration, while the molecular weight under denaturing conditions using SDS gel electrophoresis was estimated to be 27,500 . This suggests that the enzyme is composed of two subunits.

The $\alpha$-acetolactate decarboxylase had an isoelectric point at $\mathrm{pH} 4.7$ and its approximate amino acid composition is listed in Table II. The content of glutamic acid and leucine was relatively high while no methionine was found. Due to lack of material the content of cysteine and tryptophan were not determined. The purified enzyme was relatively unstable with a half-life of approx. $15 \mathrm{~min}$ at $37^{\circ} \mathrm{C}$ and $\mathrm{pH} 5$. A study of possible stabilizing agents showed bovine serum albumin (BSA) to have the best effect: $1 \mathrm{mg} \cdot \mathrm{ml}^{-1}$ of BSA increased the half-life at $37^{\circ} \mathrm{C}$ and pH 5 to $4 \frac{1}{2}$ hrs and in further experiments this concentration of BSA was added to all $\alpha$-acetolactate decarboxylase solutions. The enzyme was unstable below $\mathrm{pH} 4$ and above $\mathrm{pH}$ 9. It had the same temperature optimum as the partially purified enzyme (9) and the $\mathrm{pH}$ profile (Figure 5) showed a broad optimum around $\mathrm{pH}$ 4.5-5.0.

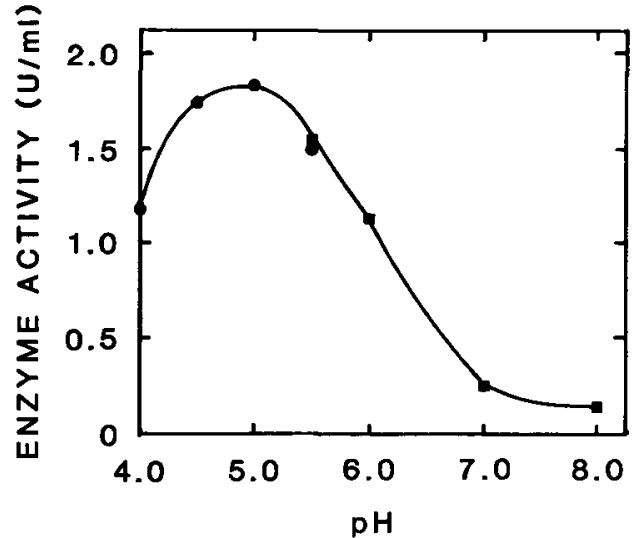

Figure 5. $\mathrm{pH}$ optimum curve for $\alpha$-acetolactate decarboxylase. The assay was performed in acetate buffer $(\rightarrow-)$ or phosphate buffer $(\rightarrow-)$ at the indicated $\mathrm{pH}$ values for $30 \mathrm{~min}$ at $37^{\circ} \mathrm{C}$, after which the acetoin formed was estimated colorimetrically.

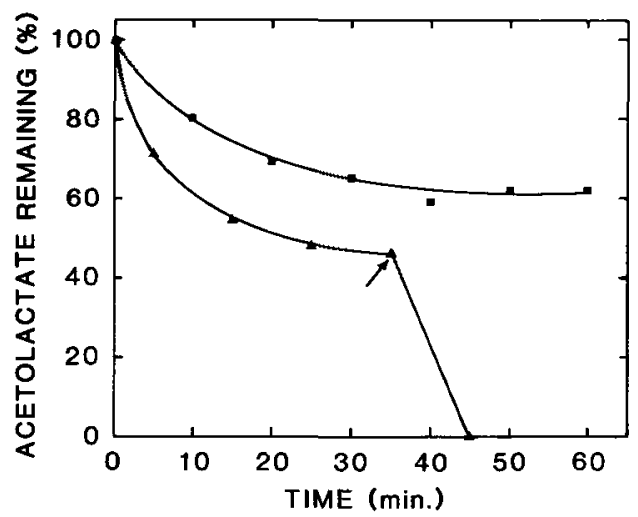

Figure 6. The degradation of $\alpha$-acetolactate by $\alpha$-acetolactate decarboxylase as judged by HPLC analysis. Solutions containing $25 \mathrm{ng}(\boldsymbol{D})$ and $75 \mathrm{ng}(\Delta)$ of purified enzyme preparation are incubated, at $37^{\circ} \mathrm{C}$, with BSA $\left(1 \mathrm{mg} \cdot \mathrm{ml}^{-1}\right), \alpha$-acetolactate $\left(10 \mu\right.$ moles $\left.\cdot \mathrm{ml}^{-1}\right)$ and sodium phosphate buffer, pH $5.0\left(200 \mu\right.$ moles $\left.\cdot \mathrm{ml}^{-1}\right)$. Aliquots of these solutions were removed at various times and subjected to HPLC analysis as described. A blank value was subtracted from all measurements: this was calculated from the rate of non-enzymatic decarboxylation of $a$-acetolactate as measured by HPLC analysis (approx. $0.2 \% \cdot \mathrm{min}^{-1}$ ).

At the point indicated by the arrow $20 \mu \mathrm{l}$ of concentrated $\mathrm{H}_{2} \mathrm{SO}_{4}$ was added to the assay which brought about total decarboxylation of the remaining $\alpha$-acetolactate. 


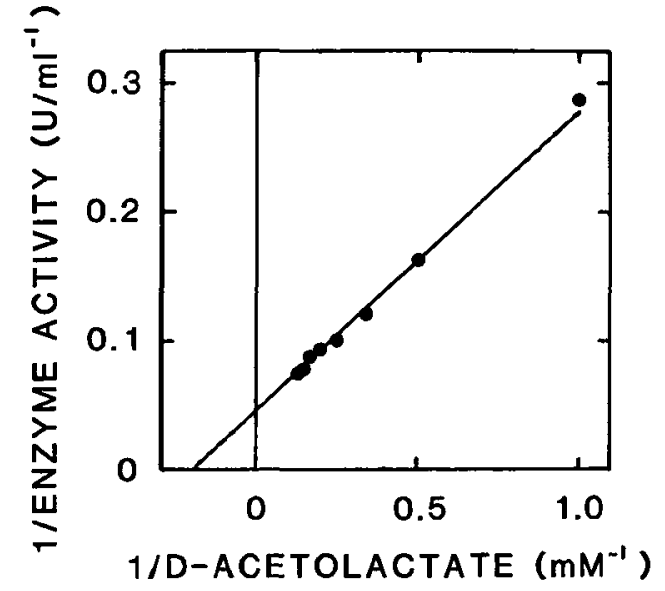

Figure 7. Double reciprocal plot of $D$ - $\alpha$-acetolactate concentration versus $\alpha$-acetolactate decarboxylase concentration. Enzyme $(0.051 \mu \mathrm{g})$ in a solution of 200 mM-acetate buffer, pH 5.0 and BSA $\left(5 \mathrm{mg} \cdot \mathrm{ml}^{-1}\right)$ was added to solutions containing various amounts of D,L- $\alpha$-acetolactate $(2-16 \mu$ moles $), 200 \mu$ moles acetate buffer, pH 5.0 and $5 \mathrm{mg}$ BSA to a final assay volume of $1 \mathrm{ml}$. The reaction was stopped after 5 minutes at $37{ }^{\circ} \mathrm{C}$ and the amount of acetoin estimated.

\subsection{Enzymatic properties}

After incubation of a solution of $(D, L)$ - $\alpha$-acetolactate $\left(10 \mu \mathrm{moles} \cdot \mathrm{ml}^{-1}\right)$ at $37{ }^{\circ} \mathrm{C}$ for 10 minutes with $1 \mathrm{kU} \alpha$-acetolactate decarboxylase in $200 \mathrm{~mm}$-acetate buffer, $\mathrm{pH} 5.0$ the optical rotation of the reaction mixture was found to be laevorotatory with a value of $-0.035^{\circ}$ at $589 \mathrm{~nm}$. This is in agreement with previously reported observations that $\alpha$-acetolactate decarboxylase decarboxylates the $D(+)$ isomer of $\alpha$-acetolactate $(11,13)$ at a high rate forming the $\mathrm{L}(-)$ isomer of acetoin resulting in a nett laevorotatory effect on the assay solution.

The HPLC analysis of the total amount of $a$-acetolactate present (section 2.2.1) confirmed that $\alpha$-acetolactate decarboxylase decarboxylates only one isomer of $\alpha$-acetolactate at a high rate $(11,13)$. Addition of acid to the enzymatically decarboxylated solution resulted in total disappearance of the peak corresponding to $\alpha$-acetolactate (Figure 6). During the enzymatic decarboxylation no racemisation of the $D$ - to the L-isomer was observed and the same was the case even after prolonged incubation at $\mathrm{pH} 4.0$.

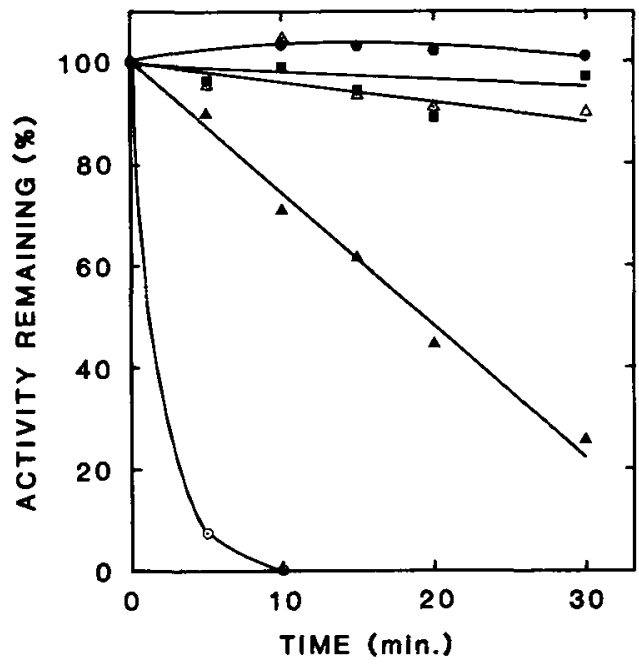

Figure 8. Inhibition of $\alpha$-acetolactate decarboxylase by various metal ion chelating agents. $0.127 \mu \mathrm{g}$ aliquots of $\alpha$-acetolactate decarboxylase were incubated at $37{ }^{\circ} \mathrm{C}$ in solutions containing metal ion chelator $(0.25$ $\mathrm{mM}), 200 \mathrm{mM}$-acetate buffer, pH 5.0, BSA (5 mg $\left.\cdot \mathrm{ml}^{-1}\right)$ in a volume of $100 \mu \mathrm{l}$. At the time intervals indicated $10 \mu \mathrm{l}$ aliquots of each solution were removed and assayed for ALDC activity. The metal ion chelators

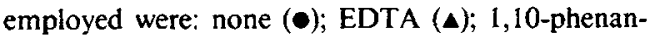
throline $(O) ; \boldsymbol{\alpha}, \boldsymbol{\alpha}$-dipyridyl $(\Delta)$ and 8-hydroxyquinoline (ם).

The colorimetric method and the HPLC method showed very similar results if the duration of the assay was kept below approx. 40 minutes, that is, before the formation of a substantial blank value occurs.

The kinetic constants were determined from the rates of decarboxylation of $\boldsymbol{\alpha}$-acetolactate over a range of $(D, L)-\alpha$-acetolactate concentrations from 2 to 16 millimolar as shown in Figure 7. The $K_{m}$ value calculated for one isomer, (D)- $\alpha$-acetolactate was $4.8 \mathrm{~mm}$ and $\mathrm{k}_{\text {rat }}$ was approximately $5.570 \mathrm{~S}^{-1}$, assuming a molecular weight of 48,000 .

\subsection{Metal requirement}

The effect of metal ion chelating agents on the activity of pure $\alpha$-acetolactate decarboxylase was investigated. Figure 8 shows the time dependent inhibition by four such agents: 1,10-phenanthroline produced rapid total inhibition, 
Table III.

Reconstitution of $\alpha$-acetolactate decarboxylase activity by divalent metal ions. Solutions of $1.3 \mu \mathrm{g}$ of $\alpha$-acetolactate decarboxylase in $500 \mu \mathrm{l}$ of $200 \mathrm{~mm}$-acetate buffer, pH 5.0 containing BSA ( $1 \mathrm{mg} \cdot \mathrm{ml}^{-1}$ ) and chelating agent (0.25 mM) were incubated at $37{ }^{\circ} \mathrm{C}$ for $10 \mathrm{~min}$ (1,10-phenanthroline) or $20 \mathrm{~min}$ (EDTA). $10 \mu \mathrm{l}$ aliqouts were then transferred to a volume of $0.8 \mathrm{ml}$ containing $1 \mu$ mole of the relevant metal ion in the above buffer and incubated for a further $10 \mathrm{~min}$ at $37^{\circ} \mathrm{C}$ after which the amount of ALDC activity was determined. A no-enzyme blank was used for each assay to account for the effect of metal ions on the absorbance at $520 \mathrm{~nm}$.

\begin{tabular}{|c|c|c|c|}
\hline \multirow{2}{*}{\multicolumn{2}{|c|}{ Assay }} & \multicolumn{2}{|c|}{$\%$ of native activity } \\
\hline & & 1,10-phenanthroline & EDTA \\
\hline \multicolumn{2}{|c|}{ Enzyme - chelating agent } & 100 & 100 \\
\hline \multicolumn{2}{|c|}{ Enzyme + chelating agent } & 6 & 27 \\
\hline - & $+\mathrm{Ba}^{2+}$ & 1 & 21 \\
\hline “ & $+\mathrm{Ca}^{2+}$ & 4 & 27 \\
\hline “ & $+\mathrm{Co}^{2+}$ & 10 & 45 \\
\hline$"$ & $+\mathrm{Cu}^{2+}$ & 2 & 1 \\
\hline “ & $+\mathrm{Fe}^{2+}$ & - & 53 \\
\hline “ & $+\mathrm{Mg}^{2+}$ & - & 26 \\
\hline “ & $+\mathrm{Mn}^{2+}$ & 0.1 & 54 \\
\hline “ & $+\mathrm{Zn}^{2+}$ & 12 & 72 \\
\hline
\end{tabular}

whilst EDTA inhibited the enzyme at a lower rate, while the remaining two chelators had only a slight effect.

These findings, together with earlier results $(9)$ imply that $\alpha$-acetolactate decarboxylase activity is dependent on a metal atom, activity being lost on removal of this metal by complexing agents. The inhibitory effect of 1,10-phenanthroline was shown to be due to its chelating properties (19) as incubation of the enzyme with 1,10-phenanthroline in the presence of excess $\mathrm{Zn}^{2+}$ ions did not inhibit activity.

Attempts were made to reconstitute the activity of the purified enzyme inhibited with metal ion chelating agents by subsequent incubation with divalent metal ions (Table III). When 1,10-phenanthroline was the chelating agent only $\mathrm{Zn}^{2+}$ and $\mathrm{Co}^{2+}$ ions had a slight stimulatory effect on enzyme activity, whereas the EDTA inhibited enzyme was reactivated by $\mathrm{Co}^{2+}, \mathrm{Fe}^{2+}$, $\mathrm{Mn}^{2+}$ and $\mathrm{Zn}^{2+}$ ions (in order of increasing effectiveness). However, full activity was not regained with any of the metal ions used and incubation of the phenanthroline treated enzyme with metal ions for longer periods than 10 minutes resulted in no further increase in activity. Other attempts to reverse the inhibition by 1,10-phenanthroline were made, such as incu- bation with combinations of metal ions or carrying out the experiment in the presence of dithiothreitol (to prevent oxidation of exposed - $\mathrm{SH}$ groups (19)), but none proved effective.

The stimulatory effect of $\mathrm{Zn}^{2+}$ ions on the phenanthroline and EDTA treated enzyme again suggest that this ion may be a constituent of $\alpha$-acetolactate decarboxylase. However, metal ion analysis of the enzyme would have to be carried out to confirm this since reconstitution of $100 \%$ activity is not possible.

Among the divalent metal ions only $\mathrm{Cu}^{2+}$ ions proved to be inhibitory. This may in part be due to complex formation between $\mathrm{Cu}^{2+}$ and acetolactate catalysing the non-enzymatic decarboxylation as described by DE MAN (2) but it seems likely that $\alpha$-acetolactate decarboxylase is directly inhibited by $\mathrm{Cu}^{2+}$ ions also.

The enzyme was found to be sensitive to inhibition by $\mathrm{p}$-hydroxy-mercuribenzoate which implies the involvement of sulphydryl groups in the active site of the enzyme.

It has been suggested by BRANEN and KEENAN (1) that thiamine pyrophosphate was essential for the activity of $\alpha$-acetolactate decarboxylase in crude extracts of L.casei. This was not confirmed in our laboratory as only addition of zinc could stabilize partially purified $\alpha$-aceto- 
lactate decarboxylase from L.casei DSM 2547 in solutions at $\mathrm{pH} 4.2$ containing yeast cells (9), addition of thiamine pyrophosphate had no effect.

\section{DISCUSSION}

The $\alpha$-acetolactate decarboxylase produced by Lactobacillus casei DSM 2547 is shown to be quite different from the enzyme described by LøKEN and STøRMER (12) from A.aerogenes, since it has higher specific activity ( 375 against $\left.4.3 \mathrm{kU} \cdot \mathrm{mg}^{-1}\right)$, lower molecular weight $(48,000$ against 73,000$)$, lower isoelectric point (4.7 against 5.6), lower $\mathrm{pH}$ optimum (5.0 against 6.2-6.4) and higher $\mathrm{K}_{\mathrm{m}}$ (4.8 against $3.4 \mathrm{~mm}$ ).

Furthermore, the $\alpha$-acetolactate decarboxylase from L.casei is found to be zinc dependent while the enzyme from A.aerogenes does not require any cofactor (12). The pure $\alpha$-acetolactate decarboxylase is unstable in diluted solutions, where partially purified preparations were stable. This can be explained by impurities stabilizing the enzyme as seen by BSA's stabilizing effect on the pure $\alpha$-acetolactate decarboxylase.

The low $\mathrm{pH}$ optimum and high specific activity of the $\alpha$-acetolactate decarboxylase from L.casei would have made this enzyme suitable as a maturation aid in beer production. However, yeast cells were found to inactivate the enzyme by removal of zinc ( 9 ). Further investigations are in progress with the aim of isolating an enzyme exhibiting a good stability and activity in fermenting wort.

\section{ACKNOWLEDGEMENTS}

ANDERS Johansen and Peter Lund are acknowledged for synthesizing the O-acetyl-acetolactate ethyl ester, ARNE OLSEN for performing the GLC and BODIL CORNELIUSSEN for carrying out the amino acid analysis. THOMAS E. MATHIASEN is gratefully acknowledged for performing the HPEC chromatography. LiLliAN ABILDGẢRD and PIA KREUTZFELD are thanked for expert technical assistance. NIKOlai Peitersen and PeER RafN from Chr. Hansens Laboratory are gratefully acknowledged for fermenting the Lactobacillus casei DSM 2547.

\section{REFERENCES}

1. Branen, A.L. \& T.W. Keenan: Biosynthesis of $\alpha$-acetolactate and its conversion to diacetyl and acetoin in cell-free extracts of Lactobacillus casei. Can. J. Microbiol. 8, 480-485 (1972)

2. DE MAN, J.C.: The formation of diacetyl and acetoin from $\alpha$-acetolactic acid. Rec. trav. chim. Pays-Bas 78, 480-486 (1959)

3. De Bussolo, J.M.: Reversed-phase liquid chromatography of proteins and peptides. Int. Biotech. Lab. 2, 14-31 (1984)

4. EgGleton, P., S.R. Elsden \& N. Gough: The estimation of creatine and of diacetyl. Biochem. J. 37, 526-529 (1943)

5. Fridovich, I: Acetoacetate decarboxylase. The Enzymes, Ed. Boyer, P.D., Academic Press. Vol. 6, 3. ed., 255-270 (1972)

6. GodTfRedSEn, S.E. \& M. Ottesen: Maturation of beer with $\alpha$-acetolactate decarboxylase. Carlsberg Res. Commun. 47, 93-103 (1982)

7. Godtfredsen, S.E., M. OtTesen, P. Sigsgárd, K. ERDAL, T. MathiaSEN \& B. AHRENST.LARSEN: Use of $a$-acetolactate decarboxylase for accelerated maturation of beer. EBC congress, Lecture No. 17 (1983)

8. GodTFREdSEN, S.E., H.LORCK \& P.SigSGäRd: On the occurrence of $a$-acetolactate decarboxylase among microorganisms. Carlsberg Res. Commun. 48, 239-247 (1983)

9. GodtFredsen, S.E., A.M. Rasmussen, M. OtTeSEN, T. MATHIASEN \& B. AHRENST-LARSEN: Application of the acetolactate decarboxylase from Lactobacillus casei for accelerated maturation of beer. Carlsberg Res. Commun. 49, 69-74 (1984)

10. Godtfredsen, S.E., A.M. Rasmussen, M. OtteSEN,P. RAFN \& N. PEITERSEN: Occurrence of $\alpha$-acetolactate decarboxylases among lactic acid bacteria and their utilization for maturation of beer. Appl. Microbiol. Biotech. 20, 23-28 (1984)

11. HILL, R.K., S. SAwADA \& S.M. ARFiN: Stereochemistry of valine and isoleucine biosynthesis IV. Bioorganic Chemistry 8, 175-189 (1979)

12. LøKEN, J.P. \& F.C. STøRMER: Acetolactate decarboxylase from Aerobacter aerogenes. Purification and Properties. Eur. J. Biochem. 14, 133-137 (1970)

13. JUNI, E.: Mechanisms of formation of acetoin by bacteria. J. Biol. Chem. 195, 715-726 (1952)

14. Pharmacia Fine Chemicals: Polyacrylamide Gel Electrophoresis. Laboratory techniques 27-28 (1980)

15. SPeCKMan, R.A. \& E.B. Collins: Diacetyl biosynthesis system in Streptococcus diacetylactis and Leuconostoc citrovorum. J. Bacteriol. 95, 174-180 (1968) 
A.M. RASMUSSEN et al.: $\alpha$-Acetolactate decarboxylase from L.casei

16. StøRmer. F.C.: 2,3-Butanediol biosynthetic system in Aerobacter aerogenes. Methods Enzymol. 4l, 518-533 (1975)

17. StøRMER, F.C.: The pH 6 acetolactate-forming enzyme from Aerobacter aerogenes. Kinetic studies. J. Biol. Chem. 243, 3735-3739 (1968)

18. UMBARGER. H.E. \& B. BROWN: Isoleucine and valine metabolism in Escherichia coli. J. Biol. Chem. 233, 1156-1160 (1958)
19. Vallee, B.L. \& A. Galdes: The metallobiochemistry of zinc enzymes. Adv. Enzymol. 56, 283-430 (1984)

20. Watt, D. \& L.O. Krampitz: $\alpha$-Acetolactic acid, an intermediate in acetylmethylcarbinol formation. Fed. Proc. 6, 301-302 (1947)

21. WeSTERFELD, W.W.: A colorimetric determination of blood acetoin. J. Biol. Chem. 161, 495-502 (1945)

Accepted by: H. KLENOW, E. Lund and S.O. ANDERSEN 